\title{
Fish herpesvirus diseases: a short review of current knowledge
}

\author{
Agnieszka Lepa, Andrzej Krzysztof Siwicki \\ Inland Fisheries Institute, Department of Fish Pathology and Immunology, Olsztyn, Poland \\ Received March 19, 2012 \\ Accepted July 16, 2012
}

\begin{abstract}
Fish herpesviruses can cause significant economic losses in aquaculture, and some of these viruses are oncogenic. The virion morphology and genome organization of fish herpesviruses are generally similar to those of higher vertebrates, but the phylogenetic connections between herpesvirus families are tenuous. In accordance with new taxonomy, fish herpesviruses belong to the family Alloherpesviridae in the order Herpesvirales. Fish herpesviruses can induce diseases ranging from mild, inapparent infections to serious ones that cause mass mortality. The aim of this work was to summarize the present knowledge about fish herpesvirus diseases.
\end{abstract}

Alloherpesviridae, $C y H V-3, C y H V-2, C y H V-1, I c H V-1, A n g H V-1$

Herpesviruses comprise a numerous group of large DNA viruses with common virion structure and biological properties (McGeoch et al. 2008; Mattenleiter et al. 2008). They are host-specific pathogens. Apart from three herpesviruses found recently in invertebrate species, all known herpesviruses infect vertebrates, from fish to mammals (Davison et al. 2005a; Savin et al. 2010). According to a new classification accepted by the International Committee on Taxonomy of Viruses (http:/ictvonline.org), all herpesviruses have been incorporated into a new order named Herpesvirales, which has been split into three families. The revised family Herpesviridae contains mammalian, avian, and reptilian viruses; the newly-created family Alloherpesviridae contains herpesviruses of fish and amphibians, and the new family Malacoherpesviridae comprises single invertebrate herpesvirus (Ostreid herpesvirus). The current taxonomy of fish herpesviruses, including most known and unassigned virus species, is shown in Table 1.

The virion of herpesviruses comprises four morphologically distinct parts: a core consisting of linear dsDNA; an icosahedral capsid; a proteinaceous tegument; a hostderived lipid envelope with viral proteins embedded in it (Davison et al. 2005b).

Although the specific virion architecture is common among all herpesviruses, the genetic relationships between three families of Herpesvirales are very tenuous. The only sequencebased evidence for a common ancestor for all herpesviruses is the gene encoding the ATPase subunit of the terminase, a protein complex which is responsible for DNA packaging into the procapsid (Davison 2002; McGeoch et al. 2006).

The family of Alloherpesviridae is a highly diverse group with a genome size ranging from $134 \mathrm{kbp}$ of channel catfish virus (the smallest sequenced genome) to $295 \mathrm{kbp}$ of cyprinid herpesvirus-3, which is the largest known genome among the order Herpesvirales (McGeoch et al. 2006; Davison 2010). The phylogenetic studies of Waltzek et al. (2009) revealed two major clades within the family Alloherpesviridae: the first comprises viruses from cyprinid and anguillid hosts, and the second comprises ictalurid, salmonid, acipenserid, and ranid taxa.

\section{Genus Cyprinivirus}

Cyprinid herpesvirus 1, also known as a carp pox virus, causes benign papillomatous lesions in the epithelium of common carp, Cyprinus carpio, and its ornamental form koi (Plumb and Hanson 2011a). Fish pox virus was found in fish in most European countries,

Address for correspondence:

Agnieszka Lepa

Inland Fisheries Institute

Department of Fish Pathology and Immunology

ul. Główna 48, Żabieniec, 05-500 Piaseczno, Poland

Phone: +48227562490

E-mail: alepa@infish.com.p

http://actavet.vfu.cz/ 
Table 1. The current taxonomy of fish herpesviruses including most known unassigned virus species (according to: Crockford et al. 2005, Davison 2010, Jakob et al. 2010, Shlapobersky et al. 2010, Marcos-Lopez et al. 2012).

\begin{tabular}{|c|c|c|c|}
\hline Taxon name & Common name & Abbreviation & Host species \\
\hline \multicolumn{4}{|l|}{ Order: Herpesvirales (wl) } \\
\hline \multicolumn{4}{|l|}{ Family: Alloherpesviridae } \\
\hline \multicolumn{4}{|l|}{ Genus: Cyprinivirus } \\
\hline Cyprinid herpesvirus-1 & Carp pox herpesvirus & CyHV-1 & Cyprinus carpio \\
\hline Cyprinid herpesvirus-2 & Goldfish haematopoietic necrosis virus & CyHV-2 & Carassius auratus \\
\hline Cyprinid herpesvirus-3 & Koi herpesvirus & CyHV-3 & Cyprinus carpio \\
\hline Anguillid herpesvirus 1 & Eel herpesvirus & AngHV-1 & $\begin{array}{l}\text { Anguilla anguilla } \\
\text { Anguilla japonica }\end{array}$ \\
\hline \multicolumn{4}{|l|}{ Genus Ictalurivirus } \\
\hline Ictalurid herpesvirus 1 & Channel catfish virus & IcHV-1 & Ictalurus punctatus \\
\hline Ictalurid herpesvirus 2 & Black bullhead herpesvirus & IcHV-2 & Ameiurus melas \\
\hline $\begin{array}{l}\text { Acipenserid herpesvirus } 2 \\
\text { Genus: Salmonivirus }\end{array}$ & White sturgeon herpesvirus 2 & AciHV-2 & Acipenser transmontanus \\
\hline Salmonid herpesvirus 1 & - & SalHV-1 & Oncorhynchus mykiss \\
\hline Salmonid herpesvirus 2 & Oncorhynchus masou herpesvirus & SalHV-2 & $\begin{array}{l}\text { Oncorhynchus nerka } \\
\text { Oncorhynchus masou }\end{array}$ \\
\hline $\begin{array}{l}\text { Salmonid herpesvirus } 3 \\
\text { Unassigned fish herpesviruses }\end{array}$ & Epizootic epitheliotropic disease virus & SalHV-3 & Salvelinus namaycush \\
\hline Acipenserid herpesvirus 1 & White sturgon herpesvirus 1 & AciHV-1 & Acipenser transmontanus \\
\hline Percid herpesvirus 1 & Walleye epidermal hyperplasia herpesvirus & PeHV-1 & Sander vitreus \\
\hline Esocid herpesvirus 1 & Northern pike herpesvirus & EsHV-1 & Esox lucius \\
\hline Pleuronectid herpesvirus 1 & Turbot herpesvirus & PlHV-1 & Scopthalmus maximus \\
\hline Osmerus eperlanus herpesvirus 1 & Comet herpesvirus of smelt & HVOE-1 & Osmerus eperlanus \\
\hline N.N. & Tilapia larvae encephalitis virus & TLEV & Oreochromis aureus \\
\hline N.N. & Pilchard herpesvirus & PHV & Sardinops sagax neopilchardus \\
\hline Gadid herpesvirus 1 & Atlantic cod herpesvirus & GaHV-1 & Gadus morhua \\
\hline
\end{tabular}

N.N.- non nominata

the United States, Israel, Russia, and in some Asian regions (China, Japan, Korea, Malaysia). Tumours found in fish are white to gray and can cover large areas of the body surface including the head and fins. Adult infected fish show no distinct behavioral or clinical signs; however, in juveniles, $\mathrm{CyHV}-1$ infection results in clinical disease and high mortality. Infected juvenile carp may develop appetite loss, distended abdomens, exophthalmia, haemorrhages on the operculum and abdomen, and darkened skin pigmentation (Plumb and Hanson 2011a). The disease is seasonal and lesions usually develop when water temperature is lower than $15^{\circ} \mathrm{C}$, and it regresses when water temperature increases (Palmeiro and Scott Weber III 2010). Sano et al. (1993) demonstrated that CyHV-1 genome is present in nervous and subcutaneous tissues after disease regression, suggesting that the virus becomes latent, which might explain the recurrence of lesions.

Cyprinid herpesvirus 2 (CyHV-2) causes herpesvirus haematopoietic necrosis in goldfish (Carassius auratus). The affected fish present no characteristic external signs except for apathy and pale gills. Histopathological investigations showed discoloration and necrosis in the spleen and kidney, and hypertrophy and hyperplasia in the gill epithelium (Jung and Miyazaki 1995; Groff et al. 1998). Disease outbreaks depend on water temperature and occur between $15-25^{\circ} \mathrm{C}$ with $50-100 \%$ mortality (Groff et al. 1998). Rapid detection of CyHV-2 is usually done with PCR techniques (Goodwin et al. 2006; Waltzek et al. 2009). 
Cyprinid herpesvirus 3 (CyHV-3, also named koi herpesvirus), first reported in 1998 (Ariav et al. 1998), is responsible for severe epizootic disease and mass mortality among Cyprinus carpio, causing enormous economic losses in carp industries worldwide (Hedrick et al. 2000; Ilouze et al. 2006). The disease affects common carp and its varieties (koi carp, ghost carp) and has spread around the world except for Australia and South America (Manual of Diagnostic Tests for Aquatic Animals 2010). Outbreaks appear seasonally when the water temperature is $18-28{ }^{\circ} \mathrm{C}$ (Perelberg et al. 2003). Affected fish exhibit apathy, gill epithelium necrosis, pale patches on the skin, pale and irregularly colored gills, increased mucus production, and enophthalmia (Hedrick et al. 2000; Pokorova et al. 2005). The study by Perelberg et al. (2003) found fry to be more susceptible to infection than mature fish. Further experimental trials conducted in Japan indicated that carp larvae (3-4 days post hatch) are resistant to CyHV-3 infection, although the same fish died when exposed to virus two months later (Ito et al. 2007). The latest research using bioluminescence imaging showed that skin is the major portal of entry for CyHV-3 in carp (Costes et al. 2009). It has been demonstrated that the virus is transmitted horizontally through fish excrement (Dishon et al. 2005) and viral particle secretion into the water (Perelberg et al. 2003). Ilouze et al. (2011) suggested that the virus might be transferred by birds moving sick fish from pond to pond. There are no data indicating that CyHV-3 is transmitted vertically. Most herpesviruses have been demonstrated to persist in the host as a latent virus, and there is some evidence suggesting that CyHV-3 can remain latent in clinically healthy fish, and that the infection can be reactivated by temperature stress (Gilad et al. 2004; Eide et al. 2011). Nested PCR, real-time PCR, and semi-nested PCR seem to be the most useful and sensitive techniques for detecting CyHV-3 (Bergmann et al. 2010). Since koi herpesvirus seems to pose the greatest threat to world carp population, most investigations are currently focused on developing efficient prophylaxis and control methods for CyHV-3 disease.

Anguillid herpesvirus 1 (AngHV-1) frequently causes disease in cultured and wild eels (Sano et al. 1990; Haenen et al. 2002). Van Beurden et al. (2010) sequenced the complete genome of the virus and confirmed that AngHV-1 is a new virus species within the family Alloherpesviridae. Although the AngHV-1 infects eels rather than cyprinid species, phylogenetic studies have shown that AngHV-1 is most closely related to the cyprinid herpesviruses (van Beurden et al. 2010). Thus, in the newest ICTV (International Committee on Taxonomy of Viruses) classification, AngHV-1 is assigned to the genus Cyprinivirus. AngHV-1 was isolated from farmed European eel (Anguilla anguilla) and Japanese eel (Anguilla japonica) in Japan (S a no et al. 1990), from Japanese eel in Taiwan (Ueno et al. 1992), and from European eel in many European countries (Davidse et al. 1999; Haenen et al. 2002; van Ginneken et al. 2004; Jakob et al. 2009). The virus was also found in wild eel populations in the Netherlands (van Ginneken et al. 2004) and Germany (Jakob et al. 2009). While clinical signs can vary among and within outbreaks, apathy, haemorrhages in the skin, fins, and gills, congested gill epithelium, and pale liver are the most frequent symptoms. Mortality ranges from 1 to $10 \%$ (S a no et al. 1990; Haenen et al. 2002). Diagnosis is usually made by virus isolation in cell culture (S ano et al. 1990; Haenen et al. 2002) or AngHV-1-specific PCR (Rijsewijk et al. 2005). Although the mortality rates are not very high, the control of disease outbreaks can be difficult because the virus is present in wild eel populations and has the ability to remain latent in apparently healthy fish (van Nieuwstadt et al. 2001).

\section{Genus Ictalurivirus}

Ictalurid herpesvirus 1 (IcHV-1) causes an acute haemorrhagic disease in cultured juvenile channel catfish, Ictalurus punctatus. Epizootics usually involve high mortality occurring in 
southern United States on commercial fish farms. Outbreaks of IcHV-1 disease have yet to be observed in wild populations suggesting that intensive fish farming may be a predictive factor. The disease occurs in the summer months, and mortality rates can reach $100 \%$ at $28^{\circ} \mathrm{C}$ (Kucuktas and Brady 1999; Davis on 2008). Clinical signs of IcHV-1 disease include erratic or spiral swimming, exophthalmia, swollen abdomen, pale or haemorrhagic gills, and haemorrhages at the fin bases and throughout the skin. Internal signs include yellowish fluid in the peritoneal cavity, dark, enlarged spleen, and extensive haemorrhages in the liver and kidneys (Smail and Munro 2001; Davison 2008; Plumb and Hanson 2011b). Transmission of the virus occurs by two routes: horizontally through the water and by direct contact; and also vertically (Kucuktas and Brady 1999). There is some evidence suggesting that survivors can be a reservoir for latent virus, which could cause disease reactivation and transmission (Davison 2008). Although IcHV-1 can cause significant losses on farms because of high mortality among young fish, its overall significance in the channel catfish industry is not very high (Plumb and Hans on 2011b).

Ictalurid herpesvirus 2 (IcHV-2), also named black bullhead herpesvirus and Ameiurine herpesvirus 1 , is associated with disease causing mass mortality among black bullhead, Ameiurus melas, in Italy (Hedrick et al. 2003). The virus causes clinical signs similar to those of IcHV-1 in channel catfish, including spiral swimming and haemorrhages in the skin and internal organs, and at the bases of fins (Hedrick et al. 2003; Plumb and Han son 2011b). Hedrick et al. showed that IcHV-2 is also pathogenic for channel catfish fry and fingerlings, which poses a potential danger to the channel catfish industry (Hedrick et al. 2003).

Acipenserid herpesvirus 2 (AciHV-2), commonly named white sturgeon herpesvirus 2 (WSHV-2), is associated with the disease of cultured and wild white sturgeon, Acipenser transmontanus, in North America and Italy. Affected fish display pale lesions on the body surface, lethargy, appetite loss, and erratic swimming. Mortality in adult fish is less than $10 \%$. Experimental studies revealed that pallid sturgeon and shovelnose sturgeon are also susceptible to AciHV-2 infection. Phylogenetic research showed that AciHV-2 is more closely related to IcHV-1 than to AciHV-1, and, according to current taxonomy of fish herpesviruses, is assigned to the genus Ictalurivirus (Hua and Wang 2005; Plumb and Hanson 2011c).

\section{Genus Salmonivirus}

Salmonid herpesvirus 1 (SalHV-1) is a causative agent of mild disease in rainbow and steelhead trout and was reported in the USA. Disease outbreaks occur when the water temperature is $10^{\circ} \mathrm{C}$ or less. It causes darkened pigmentation, apathy, pale gills, exophthalmia, and distended abdomen. In experimental trials, the virus was also pathogenic for chum salmon and chinook salmon, while brook trout, brown trout, Atlantic salmon, and coho salmon were not susceptible to SalHV-1 infection (Plumb and Hanson 2011d). Sequence analysis by Davis on (1998) indicated that SalHV-1 is closely related to SalHV-2.

Salmonid herpesvirus 2 (SalHV-2), more commonly known as Oncorhynchus masou virus, causes significant economic losses of farmed and wild salmonid fish in Japan. The susceptible fish species include masu, coho, sockeye, chum salmon, and rainbow trout. Clinical signs of the disease depend on fish age. In juveniles, the virus causes acute infection with apathy, exophthalmia, and skin ulcers, and cumulative mortality can be as high as $100 \%$ (in 1-month-old sockeye salmon). Four months to one year post infection, $12-100 \%$ of surviving fish develop tumours, located mainly around the mouth and head. SalHV-2 is transmitted horizontally through the water and vertically via ovarian fluids (Plumb and Hanson 2011d). The disease is successfully controlled in hatcheries by disinfection with iodophore of all collected eggs after fertilization and again at the earlyeyed stage (Yoshimizu and Nomura 2001). 
Salmonid herpesvirus 3 (SalHV-3) was originally found in cultured juvenile lake trout, and it causes acute disease with mortality approaching 100\%. Clinical signs are nonspecific and include lethargy interspersed with periods of hyperexcitability, spiral swimming, haemorrhages in the eyes and mouth and at the base of the fins. Histopathologically, affected fish exhibit hyperplasia, hypertrophy, and necrosis of epidermal cells. Transmission experiments showed that only lake trout and hybrids of lake and brown trout are susceptible to the disease (Bradley et al. 1989; McAllister and Herman 1989). The disease is known to appear only in the region of Great Lakes in North America when water temperatures are $6-15^{\circ} \mathrm{C}$ (Plumb and Hans on 2011d). Salmonid herpesvirus 3 is transmitted horizontally by waterborne contact (McAllister and Herman 1989), and some data suggest that it can also be transmitted vertically (Kurobe et al. 2009). Survivors of SalHV-3 infection might become long-term virus carriers (McAllister 1991).

\section{Unassigned fish herpesviruses}

Acipenserid herpesvirus 1 (AciHV-1), also known as a white sturgeon herpesvirus 1, was initially isolated from cultured juvenile white sturgeon, Acipenser transmontanus, in California (USA) hatcheries. Experimental infection resulted in a 35\% mortality rate with no specific external signs. Histopathologically, the virus causes epidermal lesions and diffused dermatitis. AciHV-1 appears to be less virulent under experimental conditions than is AciHV-2 (Plumb and Hanson 2011c).

In conclusion, the number of identified fish herpesviruses is increasing every year. Most fish herpesviruses cause mild infections in the natural environment, but under aquaculture conditions these viruses can cause severe, clinical diseases with high rates of mortality. Most of discovered alloherpesviruses are epitheliotropic, and some might be oncogenic.

These viruses are a highly diverse group, with two apparent major classes; the first includes viruses that have large genomes (anguillid and cyprinid species), while the second includes viruses that appear to possess smaller genomes like IcHV1. Although the phylogenetic connections among all herpesviruses are tenuous, fish herpesviruses share at least several structural and biological properties with other herpesvirus families: similar virion structure, many fish herpesviruses can cause persistent, life-long infections (latency), and a high level of host specificity, although there is some evidence to suggest that interspecies transmission of fish herpesviruses does exist (Waltzek et al. 2009; Bandín and Dopazo 2011).

\section{References}

Ariav R, Tinman S, Paperna I, Bejerano I 1998: First report of newly emerging viral disease of Cyprinus carpio species in Israel. In: EAFP ${ }^{\text {th }}$ international conference, Rhodes, Greece.

Bandín I, Dopazo CP 2011: Host range, host specificity and hypothesized host shift events among viruses of lower vertebrates. Vet Res 42: 67

Bergmann SM, Riechardt M, Fichtner D, Lee P, Kempter J 2010: Investigation on the diagnostic sensitivity of molecular tools used for detection of koi herpesvirus. J Virol Methods 163: 229-233

Bradley TM, Medina DJ, Chang PW, McClain J 1989: Epizootic epitheliotropic disease of lake trout (Salvelinus namaycush): history and viral etiology. Dis Aquat Org 7: 195-201

Costes B, Stalin Raj V, Michel B, Fournier G, Thirion M, Gillet L, Mast J, Lieffrig F, Bremont M, Vanderplasschen, A 2009: The major portal of entry of Koi Herpesvirus in Cyprinus carpio is the skin. J Virol 7: 2819-2830

Crockford M, Jones JB, Crane MSJ, Wilcox GE 2005: Molecular detection of a virus, Pilchard herpesvirus, associated with epizootics in Australasian pilchards Sardinops sagax neopilchardus. Dis Aquat Org 68: 1-5

Davidse A, Haenen, OLM, Dijkstra SG, van Nieuwstadt AP, van der Vorst TJK, Wagenaar F, Wellenberg GJ 1999: First isolation of herpesvirus of eel (Herpesvirus anguillae) in diseased European eel (Anguilla anguilla L.) in Europe. Bull Euro Assoc Fish Pathol 19: 137-141

Davison A, Eberle R, Hayward GS, McGeoch DJ, Minson AC, Pellett PE, Roizman B, Studdert MJ, Thiry E 2005a: Herpesviridae. In: Fauquet CM, Mayo MA, Maniloff J, Desselberger U, Ball LA(Eds): Virus taxonomy: 
classification and nomenclature of viruses, eighth report of the international committee on taxonomy of viruses. Elsevier Academic Press, London, pp. 193-212

Davison AJ 2002: Evolution of herpesviruses. Vet Microbiol 86: 69-88

Davison AJ 2008: Fish and amphibian herpesviruses. In: Mahy BWJ, van Regenmortel MHV (Eds): Desk encyclopedia of animal and bacterial virology. Elsevier Ltd, pp. 436-442

Davison AJ 2010: Herpesvirus systematics. Vet Microbiol 143: 52-69

Davison AJ Trus BL, Cheng N, Steven AC, Watson MS, Cunningham C, Le Deuff RM, Renault T 2005b: A novel class of herpesvirus with bivalve hosts. J Gen Virol 86: 41-45

Davison AJ 1998: The genome of salmonid herpesvirus 1. J Virol 72: 1974-1982

Dishon A, Perelberg A, Bishara-Sieban J, Ilouze M, Davidovich M, Werker S, Kotler M 2005: Detection of carp interstitial and gill necrosis virus in fish droppings. Appl Environ Microbiol 71: 7285-7291

Eide KE, Miller-Morgan T, Heidel JR, Kent ML, Bildfell RJ, Lapatra S, Watson G, Jin L 2011: Investigation of koi herpesvirus latency in koi. J Virol 85: 4954-4962

Gilad O, Yun S, Zagmutt-Vergara FJ, Leutenegger CM, Bercovier H, Hedrick RP 2004: Concentrations of a Koi herpesvirus (KHV) in tissues of experimentally infected Cyprinus carpio koi as assessed by real-time TaqMan PCR. Dis Aquat Organ 60:179-187

Goodwin AE, Merry GE, Sadler J 2006: Detection of the herpesviral hematopoietic necrosis disease agent (Cyprinid herpesvirus 2) in moribund and healthy goldfish: validation of a quantitative PCR diagnostic method. Dis Aquat Organ 69: 137-143

Groff JM, LaPatra SE, Munn RJ, Zinkl JG 1998: A viral epizootic in cultured populations of juvenile goldfish due to a putative herpesvirus etiology. J Vet Diagn Invest 10: 375-378

Haenen OLM, Dijkstra SG, van Tulden PW, Davidse A, van Nieuwstadt AP, Wagenaar F, Wellenberg GJ 2002: Herpesvirus anguillae (HVA) isolations from disease outbreaks in cultured European eel, Anguilla anguilla in The Netherlands since 1996. Bull Euro Asso Fish Pathol 22: 247-257

Hedrick RP, Gilad O, Yun S, Spangenberg JV, Marty GD, Nordhausen RW, Kebus MJ, Bercovier H, Eldar A 2000 : A herpesvirus associated with mass mortality of juvenile and adult koi, a strain of common carp. J Aquat Anim Health 12: 44-55

Hedrick RP, McDowell TS, Gilad O, Adkison M, Bovo G 2003: Systemic herpes-like virus in catfish Ictalurus melas (Italy) differs from Ictalurid herpesvirus 1 (North America). Dis Aquat Org 55: 85-92

Hua YP, Wang D 2005: A review of sturgeon virosis. J Forestry Res 16: 79-82

Ilouze M, Davidovich M, Diamant A, Kotler M, Dishon A 2011: The outbreak of carp disease caused by CyHV-3 as a model for new emerging viral disease in aquaculture: a review. Ecol Res 26: 885-892

Ilouze M, Dishon A, Kotler M 2006: Characterization of a novel virus causing a lethal disease in carp and koi. Microbiol Mol Biol Rev 70: 147-156

International Committee on Taxonomy of Viruses. Available at: http://ictvonline.org/. Accessed January 5, 2012.

Ito T, Sano M, Kurita J, Yuasa K, Iida T 2007: Cap larvae are not susceptible to koi herpesvirus. Fish Pathol 42: 107-109

Jakob NJ, Kehm R, Gelderblom HR 2010: A novel fish herpesvirus of Osmerus eperlanus. Virus Genes 1: 81-85

Jakob E, Neuhaus H, Steinhagen D, Luckhardt B, Hanel R 2009: Monitoring of Herpesvirus anguillae (HVA) infections in European eel, Anguilla anguilla (L.), in northern Germany. J Fish Dis 32: 557-561

Jung SJ, Miyazaki T 1995: Herpesviral haematopoietic necrosis of goldfish, Carassius auratus (L.). J Fish Dis 18: $211-220$

Kucuktas H, Brady YJ 1999: Molecular biology of channel catfish virus. Aquaculture 172: 147-161

Kurobe T, Marcquenski S, Hedrick RP 2009: PCR assay for improved diagnostics of epitheliotropic disease virus (EEDV) in lake trout Salvelinus namaycush. Dis Aquat Org 84: 17-24

Manual of Diagnostic Tests for Aquatic Animals. Diseases of fish. Koi herpesvirus disease.

World Organization of Animal Health. Available at: http://www.oie.int/fileadmin/Home/eng/Health_standards/ aahm/2010/2.3.06_KHVD.pdf. Accessed January 5, 2012.

Marcos-Lopez M, Waltzek TB, Hedrick RP, Baxa DV, Garber AF, Liston R, Johnsen E, Forward BS, Backman S, Ferguson HW 2012: Characterization of a novel alloherpesvirus from Atlantic cod (Gadus morhua). J Vet Diagn Invest 24: 65-73

Mattenleiter TC, Keil GM, Fuchs W 2008: Molecular biology of animal herpesviruses. In: Mattenleiter TC, Sobrino F (Eds): Animal viruses: molecular biology. Caister Academic Press, Norfolk, UK, pp. 375-456

McAllister 1991: Lake trout epidermal hyperplasia. Informational report 4 prepared for the Pacific Northwest Fish Health Protection Committee. Available at: http://wdfw.wa.gov/pnfhpc/pubs/ireports/LTEH.pdf. Accessed January 5, 2012.

McAllister PE, Herman RL 1989: Epizootic mortality in hatchery-reared lake trout. Salvelinus namaycush caused by a putative virus possibly of the herpesvirus group. Dis Aquat Organ 6: 113-119

McGeoch DJ, Rixon FJ, Davison AJ 2006: Topics in herpesviruses genomics and evolution. Virus Research 117: 90-104

McGeoch DJ, Davison AJ, Dolan A, Gatherer D, Sevilla-Reyes E 2008: Molecular evolution of the Herpesvirales. In: Domingo E, Parrish CR \& Holland JJ (Eds): Origin and evolution of viruses, $2^{\text {nd }}$ edition. Oxford Elsevier, pp. 447-475 
Palmeiro B, Scott Weber III E 2010: Viral pathogens of fish. In: Roberts HE (Ed.): Fundamentals of Ornamental Fish Health. Blackwell Publishing pp. 113-124

Perelberg A, Smirnov M, Hutoran M, Diamant A, Bejerano Y, Kotler M 2003: Epidemiological description of a new viral disease afflicting cultured Cyprinus carpio in Israel. Isr J Aquacult Bamidgeh 55: 5-12

Plumb JA, Hanson LA 2011a: Carp and minnow viruses. In: Plumb JA, Hanson LA (Eds): Health maintenance and principal microbial diseases of cultured fishes, $3^{\text {rd }}$ edition. Blackwell Publishing pp. 109-134

Plumb JA, Hanson LA 2011b: Catfish viruses. In: Plumb JA, Hanson LA (Eds): Health maintenance and principal microbial diseases of cultured fishes, $3^{\text {rd }}$ edition. Blackwell Publishing pp. 95-107

Plumb JA, Hanson LA 2011c: Sturgeon viruses. In: Plumb JA, Hanson LA (Eds): Health maintenance and principal microbial diseases of cultured fishes, $3^{\text {rd }}$ edition. Blackwell Publishing pp. 219-225

Plumb JA, Hanson LA 2011d: Trout and salmon viruses. In: Plumb JA, Hanson LA (Eds): Health maintenance and principal microbial diseases of cultured fishes, $3^{\text {rd }}$ edition. Blackwell Publishing pp. 147-217

Pokorova D, Vesely T, Piackova V, Reschova S, Hulova J 2005: Current knowledge on koi herpesvirus (KHV): a review. Vet Med Czech 50: 139-147

Rijsewijk F, Pritz-Verschuren S, Kerkhoff S, Botter A, Willemsen M, van Nieuwstadt T, Haenen O 2005: Development of a polymerase chain reaction for the detection of Anguillid herpesvirus DNA in eels based on the herpesvirus DNA polymerase gene. J Virol Methods 124: 87-94

Sano N, Fukada H, Sano T 1990: Isolation and characterization of a new herpesvirus from eel (Anguilla anguilla). In: Perkins TO, Cheng TC (Eds): Pathology in marine science. $3^{\text {rd }}$ edition. Academic Press, New York City, pp. $15-31$

Sano N, Moriwake M, Hondo R, Sano T 1993: Herpesvirus cyprini: a search for viral genome in infected fish by in situ hybridization. J Fish Dis 16: 495-499

Savin KW, Cocks BG, Wong F, Sawbridge T, Cogan N, Savage D, Warner S 2010: A neurotropic herpesvirus infecting the gastropod, abalone, shares ancestry with oyster herpesvirus and a herpesvirus associated with the amphioxus genome. Virol J 7: 308

Shlapobersky M, Sinyakov MS, Katzenellenbogen M, Sarid R, Don J, Avtalion RR 2010: Viral encephalitis of tilapia larvae: Primary characterization of a novel herpes-like virus. Virology 399: 239-247

Smail DA, Munro ALS 2001: The virology of teleosts. In: Roberts RJ (Ed.): Fish pathology. Elsevier Health Sciences pp, 169-253

Ueno Y, Kitao T, Chen SN, Aoki T, Kou GH 1992: Characterization of herpes-like virus isolated from cultured Japanese eels in Taiwan. Gyobyo Kenkyu (Fish Pathology) 27: 7-17

van Beurden SJ, Bossers A, Voorbergen-Laarman MHA, 1 Haenen OLM, Peters S, Abma-Henkens MHC, Peeters BPH, Rottier PJM, Engelsma MY 2010: Complete genome sequence and taxonomic position of anguillid herpesvirus 1. J Gen Virol 91: 880-887

van Ginneken V, Haenen O, Coldenhoff K, Willemze R, Antonissen E, van Tulden P, Dijkstra S, Wagenaar F, van den Thillart G 2004: Presence of virus infections in eel populations from various geographic areas. Bull Euro Assoc Fish Pathol 24: 270-274

van Nieuwstadt AP, Dijkstra SG, Haenen OLM 2001: Persistence of herpesvirus of eel Herpesvirus anguillae in farmed European eel Anguilla anguilla. Dis Aquat Organ 45: 103-107

Waltzek TB 2009: Phylogenetic relationships in the family Alloherpesviridae. Dis Aquat Organ 84: 179-194

Waltzek TB, Kurobe T, Goodwin AE, Hedrick RP 2009: Development of a polymerase chain reaction assay to detect cyprinid herpesvirus 2 in goldfish. J Aquat Anim Health 21: 60-67

Yoshimizu M, Nomura T 2001: Oncorhynchus masou virus (OMV) epidemiology and its control strategy. Bull Natl Res Inst Aquacult Suppl 5: 11-14 